\title{
PEMANFAATAN BAKTERI SEBAGAI KONTROL BIOLOGI DALAM PEMELIHARAAN LARVA UDANG WINDU (Penaeus monodon)
}

\author{
Des Roza*) dan Zafran*)
}

\begin{abstract}
ABSTRAK
Suatu penelitian pemanfaatan bakteri sebagai kontrol biologi dalam mengendalikan populasi Vibrio harveyi tetap pada batas aman telah dilakukan di Laboratorium Penyakit Loka Penelitian Perikanan Pantai Gondol, Bali. Tiga puluh lima bakteri penghambat telah berhasil diisolasi dari berbagai sumber. Penelitian telah menghasilkan dua bakteri penghambat (No. 16 dan 35) yang mempunyai daya hambat dan mampu menekan perkembangan populasi $V$. harveyi pada media pemeliharaan larva udang windu (Penceus monodon) hingga batas aman $\left(<8,35 \times 10^{4} \mathrm{cfu} / \mathrm{ml}\right)$, dan memberikan laju sintasan yang lebih tinggi dibandingkan kontrol. Kedua bakteri memberikan perbedaan yang sangat nyata $(\mathrm{P}<0,05)$ terhadap kepadatan $V$. harveyi dan sintasan dibandingkan dengan kontrol. Setelah diidentifikasi dengan serangkaian uji biologi dan biokimia, bakteri penghambat No. 16 diidentifikasi sebagai $V$. alginolyticus, sedangkan bakteri penghambat No. 35 sebagai Flavobacterium sp. Keberadaan kedua bakteri tersebut pada media pemeliharaan larva dapat dijadikan alternatif untuk mengendalikan $V$. harveyi secara biologis.
\end{abstract}

\section{ABSTRACT: Bacteriological of Luminescent Vibrio Harveyi Diseases in Penaeus Monodon Larvae. By: Des Roza and Zafran.}

An experiment of controlling Vibrio harveyi by a bacterium in Penaeus monodon larvae, was conducted in Gondol Research Station for Coastal Fisheries, Bali. Two of 35 isolates of bacterium (No. 16 and 35) were used as control agents because of their capability to inhibit the growth of $V$. harveyi on Marine Agar medium. In the larvae rearing experiment, both isolates of bacterium were found to be effective to decrease the population of $V$. harveyi in the at safety level $\left(<8.35 \times 10^{4} \mathrm{cfu} / \mathrm{ml}\right)$. The survival rate of $P$. monodon larvae treated with the bacteria isolates was found to be higher and significantly than control $(\mathrm{P}<0.05)$. This experiment used a randomized completely design. Based on biological and biochemical isolate No. 16 was identified as Vibrio alginolyticus and isolateNo. 35 as Flavobacterium sp.

\section{KEYWORDS: Bacterial, Penaeus monodon, Vibrio alginolyticus, V. harveyi, Flavobacterium sp.}

\section{PENDAHULUAN}

Budidaya udang di Indonesia sejak beberapa tahun ini mengalami penurunan dalam produksi, baik budidaya di tambak maupun pembenihan di panti benih. Terjadinya mortalitas larva udang secara masal di panti benih mengakibatkan masalah dalam budidaya perikanan di daerah pantai. Penyebab utama kematian tersebut akibat adanya serangan penyakit, yakni penyakit kunang-kunang yang disebabkan oleh bakteri bercahaya (Rukyani et al., 1992; Zafran, 1992; Roza, 1995). Penyebabnya sudah diidentifikasi sebagai $V$. harveyi (Karuna- sagar et al., 1994; Zafran dan Roza, 1992) dimana larva yang terinfeksi pada tingkat parah akan bercahaya pada kondisi gelap.

Berbagai upaya untuk menanggulangi penyakit kunang-kunang telah dilakukan, dengan menggunakan berbagai bahan kimia. Tetapi tingkat keberhasilannya sangat bervariasi dan bahkan penggunaan bahan kimia secara kontinyu dan tidak terkontrol dapat berdampak timbulnya resistensi (Baticados dan Paclibare, 1992; Ruangpan dan Kitao, 1992), yang diwaktu mendatang dapat menimbulkan masalah baru. Pada prinsipnya $V$. harveyi hanya bersifat oportunistik dan akan

\footnotetext{
Peneliti pada Loka Penelitian Perikanan Pantai Gondol, Bali
} 
menjadi patogen apabila keberadaannya dalam air pemeliharaan larva mencapai $>8,35 \times 10^{4} \mathrm{cfu} / \mathrm{ml}$ (Zafran dan Roza, 1992).

Cara yang ampuh, aman dan efektif dalam pengendalian populasi bakteri $V$. harveyi adalah secara biologis, baik menggunakan fitoplankton yang mengandung bakterisida atau dengan meng. gunakan bakteri lain sebagai musuh alaminya tetapi tidak bersifat patogen terhadap larva udang (Maeda, 1989 dan Fukami et al., 1991). Menurut Limas et al. (1975) di alam banyak terdapat organisme atau mikroba (bakteri, fungi dan actinomycetes) yang dapat memproduksi antibiotik. Roza (1995) telah berhasil mengisolasi Flavobacterium sp. dari air pemeliharaan larva udang windu dan dapat dipakai sebagai alternatif dalam menekan populasi $V$. harveyi secara biologis pada skala laboratorium.

Berdasarkan hal tersebut perlu dilakukan penelitian dengan tujuan mengisolasi dan menseleksi jenis-jenis bakteri dari lingkungan alami tempat pemeliharaan udang yang mempunyai kemampuan untuk mengendalikan perkembangan populasi $V$. harveyi, namun tidak bersifat mematikan terhadap larva udang windu. Hal ini dapat dijadikan pilihan yang berwawasan lingkungan dalam upaya menekan populasi $V$. harveyi sampai mencapai batas aman sehingga dapat meningkatkan sintasan larva.

\section{BAHAN DAN METODE}

\section{Isolasi}

\section{A. Vibrio harveyi}

Vibrio harveyi diisolasi dari air pemeliharaan larva udang windu stadia zoea-2 pada panti benih skala rumah tangga (backyard hatchery) udang di Loka Penelitian Perikanan Pantai Gondol, Bali. Contoh air diambil sebanyak 0,1 ml kemudian dikultur pada media Thiosulphate Citrate Bile Salt Sucrose Agar (TCBSA) dan diinkubasi pada suhu $27^{\circ} \mathrm{C}$ selama 8-12 jam. Terhadap koloni yang berwarna hijau dan bercahaya dalam kondisi gelap dilakukan pemurnian dengan menggunakan media Marine Agar (MA). Selanjutnya isolat tersebut diidentifikasi melalui uji biokimia dan biologi berpedoman kepada Baumann et al. (1984) dan Holt et al. (1994).

\section{B. Bakteri penghambat}

Calon bakteri penghambat diisolasi dari berbagai sumber antara lain air laut, air tandon, air pemeliharaan larva, induk dan larva udang dari panti pembenih di Bali dan Jawa Timur, dengan cara inokulasi contoh air sebanyak $0,1 \mathrm{ml}$ pada media Tryptic Soy Agar (TSA) dan TCBSA, kemudian diinkubasi pada suhu $27^{\circ} \mathrm{C}$ selama 8-12 jam. Terhadap koloni yang tumbuh dilakukan pemurnian dengan menggunakan media MA.

\section{Uji Daya Hambat Bakteri Penghambat terhadap Vibrio harveyi pada Media MA}

Semua bakteri penghambat yang telah murni di uji daya hambatnya terhadap pertumbuhan $V$. harveyi pada media MA dengan menggunakan metoda Maeda (1994), yaitu dengan cara menggoreskan bakteri penghambat, masing masing 2 kali, sepanjang $4 \mathrm{~cm}$ pada 3 lempeng MA untuk diinkubasikan masing masing selama 24, 72, dan 144 jam pada suhu $27^{\circ} \mathrm{C}$. Setelah masa inkubasi tersebut, di antara kedua goresan bakteri penghambat digoreskan bakteri ( $V$. harveyi) dengan jarak $1,5 \mathrm{~cm}$ dengan panjang goresan $2 \mathrm{~cm}$ dan diinkubasi pada suhu $27^{\circ} \mathrm{C}$. Pengamatan dilakukan setelah 24 jam terhadap kemampuan masingmasing bakteri uji untuk menghambat pertumbuhan $V$. harveyi. Bakteri penghambat dianggap mempunyai daya hambat apabila $V$. harveyi tidak mampu tumbuh atau kalaupun tumbuh tidak sebaik pertumbuhan $V$. harveyi bila digores secara tunggal (sebagai kontrol).

\section{Uji Patogenisitas Bakteri Penghambat terhadap Larva Udang Windu (Penaeus monodon)}

Terhadap bakteri yang diketahui mempunyai kemampuan menghambat pertumbuhan bakteri $(V$. harveyi) pada media MA dilakukan uji patogenisitasnya terhadap larva udang. Ke dalam botol kaca yang berisi masing masing dua liter air laut steril (dengan menggunakan autoclave pada suhu $121^{\circ} \mathrm{C}$ selama 15 menit) dan berisi hewan uji 100 ekor larva udang windu, stadia zoea-1 yang diperoleh dari panti benih Loka Penelitian Perikanan Pantai Gondol Bali, diinokulasikan suspensi masing masing bakteri penghambat dengan kepadatan $2,8 \times 10^{5}, 10^{6}, 10^{7}$, dan $10^{8}$ colony farming per unit (cfu/ml) dan kontrol (tanpa inokulasi suspensi bakteri penghambat). Setiap perlakuan diulang tiga kali. Setelah 24 jam dilakukan pengamatan terhadap mortalitas larva uji. 


\section{Uji tantang Bakteri Penghambat terhadap Pertumbuhan Vibrio harveyi}

Bakteri penghambat yang diketahui efektif menghambat pertumbuhan $V$. harveyi dan tidak patogen terhadap larva udang windu diuji tantang dengan $V$. harveyi menggunakan media Pepton Broth yang mengandung $1 \% \mathrm{NaCl}$. Larutan tersebut dibagikan kedalam enam botol masing masing sebanyak $15 \mathrm{ml}$ dan juga ke dalam tabung reaksi masing masing sebanyak $5 \mathrm{ml}$. Pada tahap pertama bakteri penghambat dikultur dalam media pepton broth $15 \mathrm{ml}$ masing masing tiga botol, kemudian diinkubasi pada suhu $27^{\circ} \mathrm{C}$ selama 24 jam (botol 1), 72 jam (botol 2), dan 144 jam (botol 3). Setelah masa inkubasi tersebut bakteri disaring dengan menggunakan saringan Millipore 0,45 mm sebanyak $10 \mathrm{ml}$. Kemudian supernatan bakteri penghambat tersebut diambil sebanyak $5 \mathrm{ml}$ dan diencerkan beberapa rangkaian dan yang terakhir baru diinokulasikan dengan menggunakan jarum ose, lalu diaduk sampai bakteri ( $V$. harveyi) tersebar merata. Tabung-tabung tersebut diinkubasi pada suhu $27^{\circ} \mathrm{C}$ selama 24 jam. Pengamatan dilakukan terhadap pertumbuhan bakteri Vibrio harveyi.

\section{Aplikasi Pemanfaatan Bakteri Penghambat dalam Pemeliharaan Larva Udang Windu (Penaeus monodon)}

\section{A. Percobaan 1}

Ke dalam bak polikarbonat yang berisi $100 \mathrm{l}$ air laut yang telah disaring dengan mikrofilter $0,45 \mathrm{~mm}$ dan disinari dengan UV, dimasukkan 500 ekor larva udang windu ( $P$. monodon) stadia nauplius-6 yang diperoleh dari panti pembenih swasta di Banyuwangi, Jawa Timur. Masing-masing bak tersebut diinokulasikan suspensi $V$. harveyi hidup dengan kepadatan 5,6 x $10^{6} \mathrm{cfu} / \mathrm{ml}$. Kemudian ke dalam bak yang dipilih secara acak tersebut selanjutnya diinokulasikan juga suspensi bakteri penghambat dengan kepadatan $6,7 \times 10^{8} \mathrm{cfu} / \mathrm{ml}$. Bak lainnya digunakan sebagai kontrol (tanpa inokulasi suspensi bakteri penghambat). Setelah tiga hari dilakukan lagi inokulasi ulang suspensi bakteri penghambat dengan kepadatan yang sama yakni $6,7 \times 10^{8} \mathrm{cfu} / \mathrm{ml}$. Penelitian ini dilakukan dengan rancangan acak lengkap dengan inokulasi masing-masing bakteri penghambat tiga ulangan. Pengamatan dilakukan terhadap kepadatan bakteri $V$. harveyi pada air pemeliharaan dan kelangsungan hidup larva udang windu sampai stadia mysis-2.

\section{B. Percobaan 2}

Ke dalam bak polikarbonat yang berisi $200 \mathrm{l}$ air laut yang difilter dengan mikrofilter $0,45 \mathrm{~mm}$ serta disinari UV, dimasukkan larva udang windu stadia nauplius-6 sebanyak 1000 ekor yang diperoleh dari panti pembenih Loka Penelitian Perikanan Pantai Gondol, Bali. Selanjutnya ke dalam bak tersebut diinokulasikan suspensi $V$. harveyi hidup dengan kepadatan $3,9 \times 10^{6} \mathrm{cfu} / \mathrm{ml}$. Dan ke dalam bak yang dipilih secara acak, diinokulasikan suspensi bakteri penghambat dengan kepadatan $3,1 \times 10^{8} \mathrm{cfu} / \mathrm{ml}$, bak yang lain adalah sebagai kontrol. Tiga hari setelah penelitian berlangsung dilakukan inokulasi ulang masing masing suspensi bakteri penghambat pada kepadatan yang sama dengan inokulasi awal $\left(3,1 \times 10^{8} \mathrm{cfu} / \mathrm{ml}\right)$. Rancangan yang digunakan adalah acak lengkap dengan perlakuan inokulasi masing-masing bakteri penghambat tiga ulangan. Pengamatan dilakukan terhadap kepadatan bakteri V. harveyi pada air pemeliharaan dan kelangsungan hidup larva sampai stadia mysis-1.

\section{Percobaan 3}

Ke dalam bak polikarbonat berisi 300 air laut yang hanya disaring dengan kantong filter, dimasukkan larva udang windu stadia nauplius-6 sebanyak 2000 ekor. Ke dalam semua bak diinokulasikan bakteri $V$. harveyi hidup pada kepadatan $2,6 \times 10^{5} \mathrm{cfu} / \mathrm{ml}$. Terhadap bak yang dipilih secara acak diinokulasikan lagi suspensi bakteri penghambat dengan kepadatan $3,4 \times 10^{7}$ cfu/ml, sedangkan tiga bak lainnya tanpa inokulasi suspensi bakteri penghambat sebagai kontrol. Inokulasi ulang masing-masing bakteri penghambat dilakukan setelah tiga hari inokulasi awal dengan kepadatan yang sama $\left(3,4 \times 10^{7} \mathrm{cfu} / \mathrm{ml}\right)$. Dalam percobaan ini rancangan yang digunakan adalah acak lengkap dengan perlakuan inokulasi masingmasing bakteri penghambat tiga ulangan. Pengamatan dilakukan terhadap kepadatan bakteri $V$. harveyi pada air pemeliharaan dan sintasan larva windu sampai stadia paska larva-1.

\section{Identifikasi Bakteri Penghambat}

Terhadap bakteri yang diuji baik untuk menghambat pertumbuhan $V$. harveyi pada media agar, uji tantang serta aplikasinya dalam air pemeliharaan larva udang windu dilanjutkan dengan identifikasi melalui serangkaian uji biologi dan biokimia berdasarkan Cowan (1974); Acuigrup (1980); Baumann et al. (1984); Holt et al. (1994). 
Untuk menguji secara sederhana apakah bakteri tersebut mengandung semacam zat penghambat, maka dilakukan uji sensitivitasnya terhadap $V$. harveyi. Adapun media yang digunakan adalah Sensitivity Disk Agar (SDA). Pertama bakteri dikultur pada media pepton broth yang mengandung $1 \% \mathrm{NaCl}$ masing masing tiga botol ( $\pm 15 \mathrm{ml}$ ), inkubasi pada suhu $27^{\circ} \mathrm{C}$ selama 24; $72 ; 144$ jam. Setelah itu bakteri dipanen dengan cara menyaringnya menggunakan Millipore $0,45 \mathrm{~mm}$ sebanyak $10 \mathrm{ml}$, kemudian diencerkan beberapa kali. Ke dalam media SDA yang sudah dikultur $V$. harveyi yang sudah diratakan, dan di permukaan SDA tersebut diletakkan kertas "sensitivity disk" yang sebelumnya sudah dicelupkan ke dalam masing-masing pengenceran supernatan bakteri penghambat. Selanjutnya inkubasi pada suhu $27^{\circ} \mathrm{C}$ selama 24 jam. Bakteri dikatakan mempunyai zat penghambat apabila ada zona di sekeliling kertas sensitivity disk yang tidak tumbuh $V$. harveyi.

\section{HASIL DAN PEMBAHASAN}

\section{Isolasi}

\section{A. Bakteri Vibrio harveyi}

Bakteri ini mempunyai karakter di antaranya dapat tumbuh pada suhu $20-35^{\circ} \mathrm{C}$, dapat mensintesa D-mannose, selobiose, tetapi tidak mampu mensintesa sukrose sehingga pada media TCBSA koloninya berwarna hijau, dan bercahaya pada kondisi gelap. Hasil penelitian ini sesuai dengan hasil penelitian Baumann et al., 1984 dan Holt et al. (1994). Untuk lebih jelas lihat pada Table 1.

\section{B. Bakteri penghambat}

Penelitian ini telah berhasil mengkoleksi 35 isolat bakteri penghambat dengan karakter koloni berwarna kuning dan hijau pada media TCBSA serta merah, hitam, jingga, kuning, jingga dan abu abu pada media TSA. Adapun pemilihan dari warna/pigmen koloni bakteri penghambat yang dikoleksi berdasarkan pada hasil penelitian dari Austin (1988) yang telah mengisolasi dua strain bakteri dengan koloni berpigmen kuning pada media MA yang dapat memproduksi antibiotik. Sedangkan Garriques dan Arevalo (1995) dari hasil penelitiannya menyatakan bahwa $V$. alginolyticus yang koloninya berwarna kuning pada media TCBSA dapat meningkatkan kelangsungan hidup dan pertumbuhan larva Penaeus vannamei secara probiotik.

\section{Uji Daya Hambat Bakteri Penghambat terhadap Pertumbuhan Vibrio harveyi pada MA}

Dari 35 bakteri penghambat yang dikoleksi diperoleh 11 isolat yang mempunyai daya hambat, tetapi yang kelihatan mampu menghambat pertumbuhan $V$. harveyi ada 2 yaitu isolat No. 16 dan 35. Hasil lengkap disajikan pada Table 2.

Berdasarkan hasil tersebut maka untuk uji patogenisitas, uji tantang dan aplikasinya dalam pemeliharaan larva digunakan bakteri penghambat No. 16 dan 35.

\section{Uji Patogenisitas Dua Bakteri Penghambat terhadap Larva Udang Windu (Penaeus monodon)}

Hasil uji bakteri penghambat yakni No. 16 dan 35 tidak berdampak kematian terhadap larva uji selama 24 jam perlakuan (Table 3).

Adapun pemilihan stadia zoea dari larva uji karena zoea merupakan stadia yang paling rawan terhadap infeksi Vibrio harveyi (Zafran dan Roza, 1992; Roza et al., 1993) di mana pada stadia ini larva sudah mempunyai saluran pencernaan dan mulai melakukan aktivitas makan dengan cara menyaring air.

\section{Uji Tantang Bakteri Penghambat terhadap Pertumbuhan Vibrio harveyi}

Hasil penelitian ini menunjukkan bahwa kedua bakteri penghambat hanya mampu menekan pertumbuhan $V$. harveyi sampai tingkat pengenceran kedua. Berarti pada pengenceran ketiga dan seterusnya $V$. harveyi dapat tumbuh dengan baik. Hal ini perlu diperhatikan pada tahap aplikasinya.

\section{Aplikasi Kedua Bakteri Penghambat dalam Pemeliharaan Larva Udang Windu (Penaeus monodon)}

\section{A. Percobaan 1}

Pada penelitian ini kepadatan suspensi bakteri Vibrio harveyi hidup yang diinokulasikan adalah 5,6 x $10^{6} \mathrm{cfu} / \mathrm{ml}$, sedangkan pemberian suspensi bakteri penghambat pada kepadatan $6,7 \times 10^{8} \mathrm{cfu} / \mathrm{ml}$. Dari hasil penelitian diperoleh data bahwa pada perlakuan pemberian suspensi bakteri penghambat memperlihatkan kepadatan bakteri $V$. harveyi dan 
Table 1. Characteristics of Vibrio harveyi were isolated from rearing water of larvae of Penaeus monodon in comparison with Baumann et al. (1984) and Holt et al. (1994).

\begin{tabular}{|c|c|c|c|}
\hline Characteristics & Isolate & $\begin{array}{c}\text { Baumann et al. } \\
(1984)\end{array}$ & $\begin{array}{c}\text { Holt et al. } \\
\quad(1994)\end{array}$ \\
\hline Gram stain & - & - & - \\
\hline Cytochrome oxidase & + & + & + \\
\hline Catalase & + & + & + \\
\hline O-F test & $F$ & $F$ & $F$ \\
\hline Motility & + & + & + \\
\hline $\mathrm{H} 2 \mathrm{~S}$ & - & - & - \\
\hline Gas from glucose & - & - & - \\
\hline \multicolumn{4}{|l|}{ Acid from: } \\
\hline - Cellobiose & + & + & + \\
\hline - Glucose & + & + & + \\
\hline - Mannose & + & + & + \\
\hline - Sorbitol & - & - & - \\
\hline - Sucrose & - & - & - \\
\hline \multicolumn{4}{|l|}{$\mathrm{NaCl}$ tolerance $(\%)$ : } \\
\hline-0.0 & - & & - \\
\hline-0.5 & + & + & + \\
\hline-3.0 & + & + & + \\
\hline-6.0 & + & + & + \\
\hline-10.0 & & - & - \\
\hline \multicolumn{4}{|l|}{ Growth on $\left({ }^{\circ} \mathrm{C}\right)$ : } \\
\hline-30 & + & + & + \\
\hline-35 & + & + & + \\
\hline-40 & - & - & - \\
\hline Growth on TCBSA & $G$ & $G / Y$ & $G / Y$ \\
\hline Luminescent & + & + & + \\
\hline
\end{tabular}
$\begin{aligned} \text { Abbreviation: } & +=\text { positive } ;-=\text { negative } ;=\text { green } ;=\text { yellow; } d=\text { different reaction; } \\ F & =\text { fermentative }\end{aligned}$

sintasan yang berbeda sangat nyata $(\mathrm{P}<0,05)$ dengan kontrol (tanpa pemberian suspensi bakteri musuh). Sedangkan antara perlakuan bakteri No. 35 dan 16 tidak memberikan perbedaan yang nyata $(\mathrm{P}>0,05)$.

Hal ini menunjukkan bahwa bakteri No. 35 dan 16 mempunyai semacam zat penghambat sehingga dapat menekan perkembangan $V$. harveyi dalam air pemeliharaan larva windu sampai kepadatan yang jauh lebih rendah yakni $3,0 \times 10^{2} \mathrm{cfu} / \mathrm{ml}$ dengan sintasan $75,5 \%$ (isolat no. 35 ) dan $3,8 \times 10^{2} \mathrm{cfu} / \mathrm{ml}$ dengan sintasan $78,6 \%$ (isolat no. 16) dibandingkan kontrol yakni $6,0 \times 10^{4} \mathrm{cfu} / \mathrm{ml}$ dengan sintasan lebih rendah $(24,4 \%)$. Hasil lengkap percobaan disajikan pada Table 4.

\section{B. Percobaan 2}

Kepadatan suspensi Vibrio harveyi hidup yang diinokulasikan adalah $3,9 \times 10^{6} \mathrm{cfu} / \mathrm{ml}$ dan suspensi bakteri penghambat yang diinokulasikan pada kepadatan $3,1 \times 10^{8} \mathrm{cfu} / \mathrm{ml}$. Setelah larva uji mencapai stadia mysis-1 diketahui bahwa perlaku- 
Table 2. Inhibitory of eleven isolated bacteria to inhibit the growth of Vibrio harveyi on MA medium.

\begin{tabular}{cccc}
\hline \multirow{2}{*}{ Treatment } & \multicolumn{3}{c}{ Incubation time (hours) } \\
\cline { 2 - 4 } & 24 & 72 & 144 \\
\hline 1 & 0.2 & 0.2 & 0.2 \\
4 & 0.1 & 0.1 & 0.1 \\
8 & 0.1 & 0.2 & 0.2 \\
15 & 0.2 & 0.1 & 0.2 \\
16 & $0.0^{*}$ & $0.0^{*}$ & $0.0^{*}$ \\
18 & 0.1 & 0.2 & 0.1 \\
25 & 0.1 & 0.2 & 0.1 \\
26 & 0.1 & 0.2 & 0.2 \\
32 & 0.1 & 0.1 & 0.1 \\
34 & 0.2 & 0.2 & 0.2 \\
35 & $0.0^{*}$ & $0.0^{*}$ & $0.0^{*}$ \\
Control & 0.9 & 1.3 & 1.6 \\
\hline Remark: * Vibrio harveyi can not grow &
\end{tabular}

Table 3. Pathogenicity of two bacterial to the larvae of Penaeus monodon for 24 hours exposure time.

\begin{tabular}{ccccc} 
& \multicolumn{5}{c}{$\begin{array}{c}\text { Averages survival rate (\%) at } \\
\text { bacteria density }(\mathrm{cfu} / \mathrm{ml})\end{array}$} \\
\cline { 2 - 5 } Treament & $10^{5}$ & $10^{6}$ & $10^{7}$ & $10^{8}$ \\
\hline 16 & 95.0 & 92.6 & 91.6 & 90.3 \\
35 & 97.3 & 94.3 & 93.3 & 91.0 \\
Control & 95.3 & 95.0 & 93.6 & 92.6 \\
\hline
\end{tabular}

Note; Average mean in each coulumn not significantly different $(P>0.05)$

Table 4. Density of Vibrio harveyi $(\mathrm{cfu} / \mathrm{ml})$ and survival rate (\%) of larvae of Penaeus monodon from zoea- 6 until mysis-2 stage.

\begin{tabular}{ccc}
\hline & \multicolumn{2}{c}{ Averages } \\
\cline { 2 - 3 } Treatment & $\begin{array}{c}\text { Density of Vibrio harveyi } \\
(\mathrm{cfu} / \mathrm{ml})\end{array}$ & $\begin{array}{c}\text { Survival rate } \\
(\%)\end{array}$ \\
\hline 16 & $3.8 \times 10^{2 a}$ & $75.5^{a}$ \\
35 & $3.0 \times 10_{2 a}$ & $78.6^{a}$ \\
Control & $6.0 \times 10^{4 b}$ & $24.4^{b}$ \\
\hline
\end{tabular}

Note: Average in a colum with the same superscript were not significantly different $(P>0.05)$ 
an pemberian suspensi bakteri No. 35 menunjukkan kepadatan bakteri Vibrio harveyi terendah yakni $5,3 \times 10^{2} \mathrm{cfu} / \mathrm{ml}$ dengan laju sintasan yang tertinggi, yaitu $78,5 \%$, diikuti pada perlakuan pemberian suspensi bakteri No. 16 dengan kepadatan $V$. harveyi $5,5 \times 10^{2} \mathrm{cfu} / \mathrm{ml}$ dan laju sintasan $78,3 \%$. Hasil terburuk diberikan oleh perlakuan tanpa pemberian suspensi bakteri (kontrol) yakni $2,5 \times 10^{4} \mathrm{cfu} / \mathrm{ml}$ untuk kepadatan $V$. harveyi dan $26,2 \%$ untuk laju sintasan. Secara statistik antar perlakuan bakteri No. 35 dan No. 16 berbeda sangat nyata $(\mathrm{P}<0,05)$ dibandingkan dengan kontrol, sedang antara kedua bakteri tersebut tidak berbeda nyata $(\mathrm{P}>0,05)($ Table 5).

\section{Table 5. Density of Vibrio harveyi $(\mathrm{cfu} / \mathrm{ml})$ and survival rate $(\%)$ of larvae of Penaeus monodon from nauplius-6 until mysis-1 stage}

\begin{tabular}{ccc}
\hline \multirow{2}{*}{ Treatment } & \multicolumn{2}{c}{ Averages } \\
\cline { 2 - 3 } & $\begin{array}{c}\text { Density of Vibrio harveyi } \\
(\text { cfu/ml) }\end{array}$ & $\begin{array}{c}\text { Survival rate } \\
(\%)\end{array}$ \\
\hline \multirow{2}{*}{16} & $5.5 \times 10^{2 a}$ & $78.3^{a}$ \\
35 & $5.3 \times 10^{2 a}$ & $78.5^{a}$ \\
Control & $2.5 \times 10^{4 b}$ & $26.2^{b}$ \\
\hline
\end{tabular}

Note: Average in a column with the same superscript were not significantly different $(P>0.05)$

\section{Percobaan 3}

Dalam percobaan ini kepadatan suspensi Vibrio harveyi hidup yang diinokulasikan adalah $2,6 \times 10^{5}$ $\mathrm{cfu} / \mathrm{ml}$, kemudian suspensi bakteri penghambat yang diinokulasikan masing-masing $3,4 \times 10^{7} \mathrm{cfu} / \mathrm{ml}$. Ternyata antara perlakuan kedua bakteri tersebut memperlihatkan hal yang sama dalam kepadatan $V$. harveyi, di mana bakteri No. 35 memberikan hasil terbaik dengan kepadatan terendah $\left(2,0 \times 10^{3}\right.$ $\mathrm{cfu} / \mathrm{ml})$ dan laju sintasan paling tinggi $(61,2 \%)$, diikuti perlakuan bakteri No. 16 pada kepadatan $V$. harveyi $3,0 \times 10^{3} \mathrm{cfu} / \mathrm{ml}$ dan sintasannya $59,8 \%$. Kontrol memperlihatkan hasil yang terburuk di mana kepadatan bakterinya tertinggi $\left(2,6 \times 10^{5}\right.$ $\mathrm{cfu} / \mathrm{ml}$ ) dengan kematian total larva uji. Secara statistik antara perlakuan bakteri tidak berbeda nyata $(P>0,05)$, tetapi dibandingkan dengan kontrol berbeda sangat nyata $(\mathrm{P}<0,05)$ (Table 6).

Rencananya percobaan 3 ini akan dilakukan sampai larva memasuki stadia pascalarva-1, tetapi karena pada kontrol setelah dilakukan sampling menunjukkan semua hewan uji tidak ada yang hidup lagi maka dilakukan pemanenan. Hal ini disebabkan oleh air yang digunakan sebagai media hidup larva tidak disaring dengan mikrofilter dan juga tidak di UV seperti pada percobaan 1 dan 2 , maksudnya supaya mudah diaplikasikan pada panti benih.

Dari hasil penelitian ini jelas terlihat manfaat dari keberadaan bakteri penghambat pada air pemeliharaan larva. Dengan demikian dua bakteri tersebut yang telah diisolasi dari lingkungan hidup udang dapat dijadikan alternatif dalam menekan populasi $V$. harveyi sampai batas aman secara biologis. Pada prinsipnya $V$. harveyi hanya bersifat oportunistik patogen, dan akan patogen kalau pada media pemeliharaan terjadi goncangan seperti perubahan suhu, $\mathrm{pH}$, salinitas, dan faktor lainnya secara drastis (Brackett, 1992). Larva yang terinfeksi $V$. harveyi hepatopankreasnya akan mengalami penyusutan dan warnanya berubah menjadi coklat kehitaman, dan larva akan bercahaya dalam keadaan gelap. Hal tersebut menandakan bahwa dalam tubuh larva telah terjadi akumulasi bakteri $V$. harveyi. Secara histopatologi terlihat bahwa hepatopankreas telah hancur dan dipenuhi oleh bakteri gram-negatif yang berbentuk batang (Roza dan Zafran, 1992). $V$. harveyi akan bersifat patogen kalau keberadaannya pada air pemeliharaan larva mencapai > 8,35 x $10^{4} \mathrm{cfu} / \mathrm{ml}$ (Zafran dan Roza, 1992). Ini erat hubungannya dengan hasil peneli- 


\section{Table 6. Density of Vibrio harveyi $(\mathrm{cfu} / \mathrm{ml})$ and survival rate (\%) larvae of Penaeus monodon from nauplius- 6 untill mysis-1 stage.}

\begin{tabular}{ccc}
\hline \multirow{2}{*}{ Treatment } & \multicolumn{2}{c}{ Averages } \\
\cline { 2 - 3 } & $\begin{array}{c}\text { Density of Vibrio harveyi } \\
(\mathrm{cfu} / \mathrm{ml})\end{array}$ & $\begin{array}{c}\text { Survival rate } \\
(\%)\end{array}$ \\
\hline \multirow{2}{*}{ Control } & $3.0 \times 10^{3 a}$ & $59.8^{a}$ \\
35 & $2.0 \times 10^{3 a}$ & $61.2^{a}$ \\
Con & $2.6 \times 10^{5 b}$ & $0.0^{b}$ \\
\hline
\end{tabular}

Note: Average in a column with the same superscript were not significantly different $(P>0.05)$

tian yang telah dilakukan Roza (1995) di mana keberadaan Flavobacterium sp. pada media pemeliharaan larva udang dapat menekan perkembangan $V$. harveyi di bawah batas aman.

\section{Identifikasi Bakteri Penghambat}

Berdasarkan hasil penelitian sebelumnya diketahui bahwa bakteri penghambat No. 16 dan 35 mempunyai kemampuan yang baik menekan perkembangan populasi Vibrio harveyi pada media pemeliharaan larva udang windu. Untuk mengetahui lebih jelas genus dan spesies bakteri tersebut, maka dilakukan serangkaian uji biologi dan bio-kimia.

Dari hasil uji karakteristik secara biologi dan biokimia tersebut dapat disimpulkan bahwa bakteri No. 16 diidentifikasi sebagai Vibrio alginolyticus dengan karakter diantaranya adalah gram negatif, tumbuh pada temperatur $20-42^{\circ} \mathrm{C}$, koloninya melayang pada media padat, dapat mensintesa sukrose sehingga koloninya berwarna kuning pada media TCBSA tetapi tidak memproduksi cahaya (Table 7). V. alginolyticus bukanlah penyebab penyakit utama tetapi hanya bersifat sekunder, misalnya pada ikan belanak dapat mengakibatkan "red spot" (Burke and Rodgers, 1981). Tetapi dari penelitian Garriques and Arevalo (1995) diketahui bahwa secara probiotik $V$. alginolyticus dapat meningkatkan pertumbuhan dan kelangsungan hidup larva Penaeus vannamei. Sedang bakteri No. 35 setelah dilakukan karakterisasi dengan uji biologi dan biokimia, maka lebih mendekati sebagai Flavobacterium sp. Karakternya antara lain dapat hidup di perairan tawar dan laut (Austin and Austin, 1987), gram negatif, koloninya mengandung pigmen kuning oranye pada media MA/TSA dengan diameter 0,5-1 mm, tidak bercahaya, arginin positif, motil, an aerob, tumbuh pada suhu $10-25^{\circ} \mathrm{C}$, dapat mensintesa arabinose, terjadinya sel biasanya terbentuk dalam rantai yang terdiri dari dua atau tiga sel. Pada prinsipnya Flavobacterium sp. tidak bersifat patogen, tetapi hanya berperan dalam proses infeksi (Austin and Austin, 1987).

Rosenfeld dan Zobell (1947) telah menemukan bakteri dari laut yang dapat memproduksi antibiotik. Bahkan Austin (1988) telah mengisolasi dua strain bakteri dengan karakter antara lain koloninya berpigmen kuning, gram negatif, motil, tumbuh pada temperatur $10-25^{\circ} \mathrm{C}$, resisten terhadap vibriostatic agent, indole negatif, dan dapat memproduksi antibiotik.

Untuk mengetahui zat penghambat yang dikeluarkan oleh bakteri penghambat maka dilakukan uji sensitivitasnya dalam menghambat Vibrio harveyi pada SDA, dengan melihat apakah ada zona/daerah di sekeliling kertas sensitivity disk yang tidak ditumbuhi oleh $V$. harveyi. Ternyata dari kedua bakteri penghambat yang diuji memperlihatkan hasil yang hampir sama yakni $V$. harveyi tidak tumbuh sampai pengenceran lima kali. Berarti bakteri penghambat untuk menekan pertumbuhan $V$. harveyi mengeluarkan semacam zat penghambat yang dapat diproduksinya. Sebetulnya antibiotika adalah bahan kimia yang dihasilkan oleh organisme hidup yang dapat menghambat dan membunuh mikroba (Limas et al., 1975). Organisme yang dimaksud adalah bakteri, actinomycetes dan fungi, walaupun ada algae dan beberapa tanaman berbiji yang juga dapat bersifat antagonisme. 
Table 7. Characteristics of two bacteria in comparison with Flavobacterium sp. by Cowan (1974); Acuigrup (1980), and Vibrio alginolyticus by Baumann et al. (1984); Holt et al. (1994)

\begin{tabular}{|c|c|c|c|c|c|c|}
\hline Characteristics & $\begin{array}{c}\text { Isolate } \\
\text { No. } 16\end{array}$ & $\begin{array}{c}\text { Baumann } \\
\text { et al. } \\
\text { (1984) }\end{array}$ & $\begin{array}{c}\text { Holt } \\
\text { et al. } \\
\text { (1994) }\end{array}$ & $\begin{array}{c}\text { Isolate } \\
\text { No. } 35\end{array}$ & $\begin{array}{c}\text { Cowan } \\
\text { (1974) }\end{array}$ & $\begin{array}{c}\text { Acuigrup } \\
\text { (1980) }\end{array}$ \\
\hline Gram stain & - & - & - & - & - & - \\
\hline Swarming on $M A$ & + & + & + & - & - & $N t$ \\
\hline Catalase & + & + & + & + & + & + \\
\hline Oxidase & + & + & + & + & + & + \\
\hline$O-F$ test & $F$ & $F$ & $F$ & $O$ & $N t$ & $O$ \\
\hline Motility & + & + & + & + & - & + \\
\hline$H_{2} S$ & - & - & - & - & - & \\
\hline Indole & + & + & + & - & & - \\
\hline Gas from glucose & - & - & & - & & - \\
\hline L-Arginin & + & + & + & + & + & + \\
\hline L-Ornithin & - & & - & - & - & - \\
\hline Lysin & - & - & - & - & - & \\
\hline Gelatin & + & + & + & - & + & - \\
\hline \multicolumn{7}{|l|}{ Acid from: } \\
\hline Arabinose & - & - & - & + & $N t$ & + \\
\hline Glucose & + & + & + & - & - & - \\
\hline Lactose & - & - & - & - & - & - \\
\hline Sucrose & + & + & + & - & - & $N t$ \\
\hline Xylose & - & - & $N t$ & - & $N t$ & - \\
\hline Luminescent & . & - & - & - & - & - \\
\hline \multicolumn{7}{|l|}{ Growth on: } \\
\hline SS agar & $N t$ & $N t$ & $N t$ & - & . & $N t$ \\
\hline$M C$ agar & $N t$ & $N t$ & $N t$ & + & + & $N t$ \\
\hline TCBS agar & $Y$ & $Y$ & $Y$ & - & - & - \\
\hline \multicolumn{7}{|l|}{ Growth at $\left({ }^{\circ} \mathrm{C}\right)$} \\
\hline 30 & + & + & + & + & + & + \\
\hline 35 & + & + & + & + & + & + \\
\hline 42 & + & + & + & - & - & - \\
\hline Pigmentation & - & - & - & Yo & Yo & Yo \\
\hline
\end{tabular}

Abbreviation : + = positive; - = negative; Nt=not tested; $Y=$ yellow; $Y_{0}=$ yellow orange;

$F=$ fermentative; $O=$ oxidative

\section{KESIMPULAN DAN SARAN}

Dari penelitian telah berhasil diisolasi dua isolat bakteri penghambat yang diketahui mampu menekan perkembangan populasi Vibrio harveyi pada batas aman $\left(<8,35 \times 10^{4} \mathrm{cfu} / \mathrm{ml}\right)$, sehingga laju sintasan larva udang windu dapat ditingkatkan. Bakteri tersebut setelah dilakukan uji biokimia dan biologi diidentifikasi sebagai Vibrio alginolyticus (No. 16) dan Flavobacterium sp (No. 35).

Perlu dilakukan uji lanjut untuk mengetahui kepadatan efektif bakteri Flavobacterium sp dan Vibrio alginolyticus sehingga dapat mempertahankan kondisi aman. Selain itu perlu diteliti lebih lanjut untuk mengetahui zat penghambat yang terkandung pada kedua bakteri tersebut.

\section{UCAPAN TERIMA KASIH}

Kepada Slamet Haryanto yang telah banyak membantu dalam pelaksanaan penelitian ini penulis mengucapkan terima kasih.

\section{PUSTAKA}

Acuigrup. 1980. Flavobacteriosis in Coho Salmon (Onchorhynchus kisutch) In Ahne. W. (Ed.). Fish Diseases Third COPRAQ-Session, Berlin, SpringerVerlag. pp. 212-217. 
Austin, B., and D.A. Austin. 1987. Bacterial Fish Pathogens: Diseases in Farmed and Wild Fish. pp. 225-244. Ellis Horwood Limited, England.

Austin, B. 1988. Marine Microbiology. Cambridge University Press. England. 222 p.

Baticados, M.C.L., and J.D. Paclibare. 1992. The use of chemotherapeutic agents in aquaculture in the Philippines. pp. 531-546 In M. Shariff, R.P. Subasinghe and J.R. Arthur (Ed.). Diseases in Asian Aquaculture I. Fish Health Section, Asian Fish. Soc., Manila, Philippines.

Baumann, P., A.L. Furniss, and J.V. Lee. 1984. Facultatively an Aerobic Gram-negative rods. pp. 518538 In N.R. Krieg (Ed.) Bergey's Manual of Systemic Bacteriology. Vol. 1. Williams \& Wilkins, Baltimore, USA.

Brackett, J.B. 1992. Trends in aquatic diseases control. Asian Fisheries Society. Third Asian Fisheries Forum, Singapura, 26-30 October 1992.

Burke, J. and L. Rodgers. 1981. Identification of pathogenic bacteria associated with the occurrence of "red spot" in sea mullet, Mugil chepallus L., in southeastern Queensland. J. of Fish Diseases (3):153-159.

Cowan, S.T. 1974. Manual for identification of medical bacteria ( $2^{\text {nd }}$ edition).Cambridge University Press, England. 238 p.

Fukami, K. A. Yuzawa and T. Nishijima. 1991. Isolation and properties a bacterium inhibiting the growth of Gymnodinium nagasakiense. Nippon Suisan Gakkaishi, 58(6):1073-1077.

Garriques, D., and G. Arevalo. 1995. An evaluation of the production and use of a live bacterial isolate to manipulate the microbial flora in the commercial production of Penaeus vannamei post larvae in Equador. pp. 53-59. Granjas Marinas El Rosario S.A., Guayaquil, Equador.

Holt, J.G., N.R. Krieg, P.H.A. Sneath, J.T. Staley, and S.T. Williams. 1994. Facultatively an aerobic gram negative rods. pp.259-274 In P.H.A. Sneath, J.T. Staley, D.J. Brenner, J.G. Holt, R.W. Castenholz, K. Schleifer, J.G. Tully, J. Ursing, S.T. Williams (Ed.), Bergey's Manual of Systemic of Deterinative Bacteriology. Ninth Edition. William \& Wilkins, Baltimore, USA.

Karunasagar, I., R. Pai, G.R. Malathi, and I. Karunasagar. 1994. Mass mortality of Penaeus monodon larvae due to antibiotic-resistant Vibrio harveyi infection. Aquaculture, 128:203-209.

Lavilla-Pitogo, C.R., L.C. Albright, M.C. Paner, and N.A. Sunaz. 1992. Studies on the sources of luminescent Vibrio harveyi in Penaeus monodon hatcheries. pp. 157-164. In M. Shariff, R.P. Subasinghe, and J.R. Arthur (Ed.). Diseases in Asian aquaculture I. Fish Health Section, Asian Fisheries Society, Manila, Philippines.

Limas, B.H, Y.K. Dewipadma, dan S.L. Angka. 1975. Mikrobiologi umum. 93 p. Proyek Peningkatan/ Pengembangan Perguruan Tinggi, Institut Pertanian Bogor.

Maeda, M. 1989. Some aspects of biocontrolling method in aquaculture.Jap.Soc.Mar. Biotechnol. pp. 395-397.

Maeda, M. 1994. Biocontrol of the larvae rearing biotype in aquaculture. Bull. Natl. Res. Inst. Aquaculture Suppl. 1:71-74.

Rosenfeld, W.D., and C.E. Zobell. 1947. Antibiotic production by marine microorganisms. J. of Bacteriology, 54:393-398.

Roza, D. dan Zafran. 1992. Karakteristik beberapa isolat bakteri bercahaya yang diisolasi dari larva udang windu, Penaeus monodon. J. Penel. Budidaya Pantai, 8(3):93-98.

Roza, D., Zafran, dan T. Ahmad. 1993. Penanggulangan penyakit udang windu, Penaeus monodon di panti pembenih. pp. 9-12. Prosiding Seminar Hasil Penelitian Perikanan Budidaya Pantai, Maros, 16-19 Juli 1993.

Roza, D. 1993. Pengendalian populasi bakteri Vibrio harveyi di hatchery udang windu. Prosiding Simposium Perikanan Indonesia I, Jakarta, 25-27 Agustus 1993. 5 p.

Roza, D. 1995. Uji coba penggunaan Flavobacterium sp. sebagai kontrol untuk pengendalian Vibrio harveyi di hatcheri udang windu (Penaeus monodon). 10 p. Disajikan pada Seminar Ilmiah XII dan Kongres Nasional Biologi XI, Depok, 24-27 Juli 1995.

Ruangpan, L., and T. Kitao. 1992. Minimal Inhibitory Concentration of 19 Chemotherapeutants againts Vibrio harveyi of Shrimp, Penaeus monodon. pp. 135142 In M. Shariff, R.P. Subasinghe, and J.R. Arthur (Ed.). Diseases in Asian Aquaculture I. Fish Health Section, Asian Fish. Soc., Manila, Philippines.

Rukyani, A., P. Taufik, dan Taukhid. 1992. Penyakit kunang-kunang (Luminescent vibriosis) dan Cara Penanggulangannya di Hatchery Udang Windu. pp. 47-60. Prosiding Seminar Sehari Upaya Penanggulangan Penyakit Benur Pada Hatchery Udang, Surabaya, 20 Februari 1992.

Zafran dan D. Roza. 1992. Upaya penanggulangan penyakit bakteri bercahaya pada larva udang windu, Penaeus monodon. Prosiding Temu Karya Ilmiah, Denpasar, 3-4 Desember 1992.

Zafran. 1992. Pencegahan penyakit kunang-kunang pada larva udang windu (Penaeus monodon). Prosiding Seminar Sehari Upaya Penanggulangan Penyakit Benur Pada Hatchery Udang, Surabaya, 20 Februari 1992. 